\title{
铝阳极氧化膜纳米孔阵列结构的自组织过程分析 *
}

\author{
巩运兰 ${ }^{1,2}$ 王 为 ${ }^{1}$ 王 惠 ${ }^{1}$ 郭鹤桐 1 \\ ( 1 天津大学化工学院, 天津 $300072 ; 2$ 天津商学院工程学院, 天津 300134 )
}

\begin{abstract}
摘要 提出了在铝阳极氧化膜的生长过程中存在两种力的作用, 一种是在阻挡层形成时就已经存在的由于基体 铝与氧化铝之间晶格不匹配产生的内应力的作用, 另一种是随着纳米孔的形成, 存在于纳米孔内壁的表面张力 的作用. 铝阳极氧化膜纳米孔阵列的自组织过程是在这两种力的共同作用下进行的. 这两种力的大小随着纳 米孔形貌的变化而改变, 当铝阳极氧化膜中的纳米孔呈规则的六角排列时, 这两种力达到平衡, 此时体系的能量 也最低。
\end{abstract}

关键词: 铝阳极氧化膜, 纳米孔阵列结构, 自组织, 内应力, 表面张力 中图分类号: $\mathrm{O} 646.542, \mathrm{TQ153.6}$

采用电化学技术, 在酸性电解液中通过对铝材 实施阳极氧化处理, 可在其表面制备出具有纳米孔 阵列结构的铝阳极氧化膜 ${ }^{[1]}$. 具有纳米孔阵列结构 的铝阳极氧化膜已经广泛应用于纳米材料的制备 及催化、气体吸收、分离膜等 ${ }^{[2-3]}$. 随着铝阳极氧化 膜应用的日益广泛, 对其性能和结构的要求也越来 越高, 制备高度规则六角排列的纳米孔膜已经成为 其发展的必然趋势。目前许多研究 ${ }^{[4-5]}$ 表明, 通过二 次阳极氧化或延长阳极氧化时间, 可以制备出具有 规则六角排列纳米孔的铝阳极氧化膜, 很多研究者 将这种现象解释为在阳极氧化过程中纳米孔的生 长伴随着纳米孔的自组织过程. 目前大多数的研 究都集中在利用由二次阳极氧化法制备的铝阳极 氧化膜作为模板, 合成其它的纳米材料 ${ }^{[4-5]}$, 对阳极 氧化过程中纳米孔自组织过程的内在动力及其影 响因素没有做出解释. Hideki 等 ${ }^{[2]}$ 只是将第二次阳 极氧化时单个纳米孔的形成归结为几何因素的影 响. 本文着眼于探求多孔膜自组织过程的内在驱 动力, 从多孔膜形成过程的受力分析人手, 提出了 自组织过程的形成机制.

\section{1 实验部分}

\section{1 铝阳极氧化膜的制备}

采用直流恒压电解的方法对铝试样进行阳极 氧化处理, 以制备具有纳米孔阵列结构的铝阳极氧
化膜. 以厚 $0.6 \mathrm{~mm}$ 、纯度 $99.999 \%$ 的高纯铝片为 阳极, 反应区面积 $3 \mathrm{~cm}^{2}$. 以钛基镀 $\mathrm{Pt}$ 网为阴极. 试样在 $500{ }^{\circ} \mathrm{C}$ 的温度下, 退火 $8 \mathrm{~h}$, 去氧化膜预处理 后 ${ }^{[1]}$, 立即放人 $w=3 \%$ 的草酸 (分析纯) 电解液中, 在 $40 \mathrm{~V}$ 电解电压下, 室温进行阳极氧化处理。

\section{2 铝阳极氧化膜纳米孔形貌的表征}

将氧化后的铝阳极在 $\mathrm{CuCl}_{2}\left(0.1 \mathrm{~mol} \cdot \mathrm{L}^{-1}\right)$ 和 $\mathrm{HCl}(w=20 \%)$ 的混合液中去掉铝基体, 在 $w=5 \%$ 的 $\mathrm{H}_{3} \mathrm{PO}_{4}$ 中去掉铝阳极氧化膜底部的阻挡层, 采用 英国 PHILIPS 公司产 XL30 ESEM TMP 型环境扫 描电子显微镜 (ESEM), 对铝阳极氧化膜底部的纳 米孔形貌进行表征。

\section{3 铝阳极氧化膜 $\mathrm{X}$ 射线衍射 (XRD) 分析}

采用电化学方法, 将铝阳极氧化膜从铝基体上 剥离, 采用 D/max-2500 型 X 射线衍射仪分析铝阳 极氧化膜的晶体结构。

\section{2 实验结果与讨论}

\section{1 阳极氧化时间对纳米孔阵列结构的影响}

经不同时间阳极氧化形成的氧化铝多孔膜的 ESEM 照片示于图 1. 从图中可以看出, 经 $2 \mathrm{~h}$ 阳极 氧化处理形成的铝阳极氧化膜的纳米孔的孔形为 不规则的多边形, 纳米孔排列混乱, 孔径不均匀 (图 1a). 经 $4 \mathrm{~h}$ 阳极氧化后形成纳米孔的孔形已趋于圆 形, 其中 $30 \%$ 的孔已近乎圆形, 孔径比阳极氧化 $2 \mathrm{~h}$

2003-06-20 收到初稿, 2003-09-04 收到修改稿。联系人: 王 为 (E-mail: wwangg @ tju. edu. cn; Tel: 022-27405898, 022-27402895; Fax: 022-27405898)。*国家自然科学基金(50071040)资助项目 

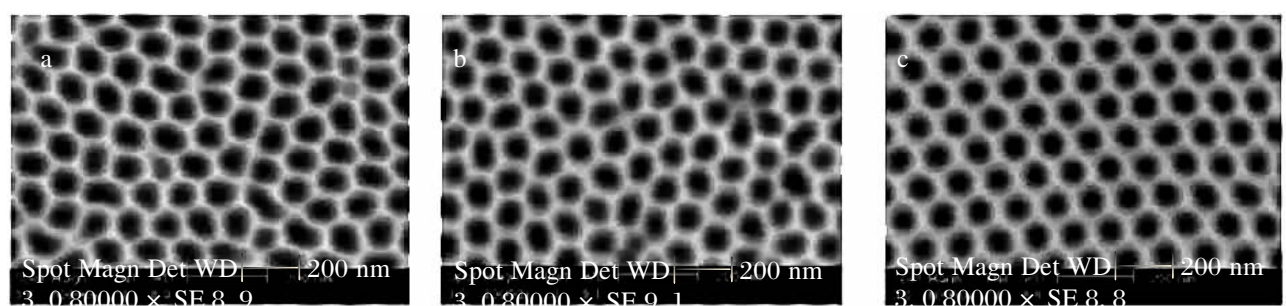

图 1 经不同时间阳极氧化形成的铝阳极氧化膜的 ESEM 形貌

Fig. 1 ESEM photos of anodizing alumina film formed in different times $t / \mathrm{h}$ : a ) 2 ; b ) 4 ; c ) 6

的更加均匀(图 1b). 当阳极氧化时间达到 $6 \mathrm{~h}$ 时, 形成的铝阳极氧化膜的纳米孔已经排列成规则的 六角蜂窝结构, 孔形为孔径均匀一致的圆孔, 纳米 孔均匀分布(图 lc).

图 2 (a) 为铝材经 $4 \mathrm{~h}$ 阳极氧化后测得的 $\mathrm{X}$ 射 线衍射分析, 图中位于 $2 \theta=27^{\circ}$ 的馒头形峰为非晶 态 $\mathrm{Al}_{2} \mathrm{O}_{3}$. 图 2(b) 为铝基材的 $\mathrm{X}$ 射线衍射分析, 图 中位于 $2 \theta$ 为 $45^{\circ} 、 65^{\circ} 、 78^{\circ}$ 的尖峰是晶态铝的 XRD 衍射峰。铝阳极氧化膜的馒头形 XRD 衍射峰显示 其具有非晶态晶体结构, 而基体铝尖锐的 XRD 衍 射峰证明其具有晶态结构。

\section{2 关于自组织过程的讨论}

研究表明 ${ }^{[1]}$, 氧化铝多孔膜形成过程分三个阶
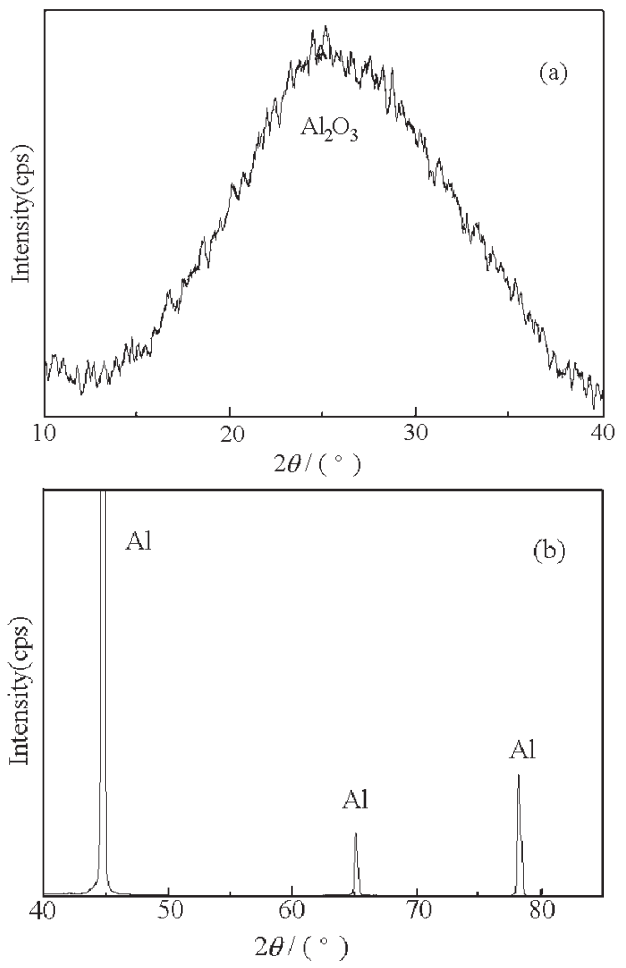

图 2 铝阳极氧化膜 (a)与铝基体 (b) 的 XRD 图

Fig. 2 XRD spectra of alumina film (a) and

Al matrix (b)
段: 阻挡层形成, 微孔的萌生, 多孔膜的生长, 图 2 的 XRD 分析证明, 氧化铝阻挡层具有非晶态结构, 与晶体铝之间晶格严重不匹配, 以及铝基体与阻挡 层密度的巨大差异 (分别是 2.7 和 $3.4 \mathrm{~g} \cdot \mathrm{cm}^{-3}$ ), 导致阻挡层内部产生很大的内应力, 该内应力为拉 应力. 在拉应力的作用下阻挡层开始产生微裂纹 以降低内应力, 微裂纹的出现改变了阻挡层表面的 电场分布, 造成微裂纹处电力线集中, 电场增强. 微裂纹处的局部高电场将加速该处氧化铝的溶解, 导致微孔萌生. 可以认为, 阳极氧化初期形成的阻 挡层中存在的拉应力成为随后萌生纳米孔的内在 动力. 由于阳极氧化初期阻挡层内产生的微裂纹 分布不均匀, 致使由微裂纹萌生的微孔的孔形及微 孔分布亦不均匀, 因而阳极氧化初期形成的纳米孔 极不规则, 其排列也杂乱无章 . 此时的多孔膜中, 不仅存在于孔壁中的内应力分布不均, 不同孔径纳 米孔内壁的表面能的大小也不等。由于整个体系 受力不均, 这个阶段形成的氧化膜是一个不稳定的 体系. 随着阳极氧化的进行, 新生氧化膜将通过微 孔结构的逐步调整, 使随后生成的氧化膜各部分的 受力逐渐趋于均衡, 向稳定状态过渡. 对阳极氧化 生成的微孔而言, 以圆形孔的表面积最小. 因此,



图 3 铝阳极氧化膜断面的 ESEM 形貌

Fig. 3 Cross-sectional ESEM photos of anodizing alumina film 
伴随着纳米孔的不断生长, 纳米孔的截面形状将由 多边形向圆形逐渐过渡. 铝阳极氧化膜的纳米孔为 贯穿孔 (图 3, 亦称为纳米管), 对长度相同而孔径不 同的纳米孔而言, 表面能的大小与孔径成正比, 即孔 径越大, 表面能越大. 为使整个体系的表面能均匀 分布, 在氧化膜的生长过程中, 较大的孔径会逐渐减 小, 较小的孔径会逐渐增大, 经过长时间的阳极氧化 后, 氧化膜中的微孔最终达到孔径一致 (图 1c). 对 于圆形铝阳极氧化膜的纳米孔而言, 具有六方密堆 结构是具有相同孔径圆形微孔的最致密排列方式, 采取这样的排列方式可以保证最大限度地降低体系 能量, 使体系达到稳定状态。

总之, 伴随着氧化膜的生长, 氧化铝内部的拉应 力将通过其内部形成的大量纳米级微孔得到松驰. 但大量微孔的形成, 必然导致表面能的急剧增加, 使
体系的能量增大. 当存在于孔壁内部的拉应力与存 在于孔壁表面的表面张力最终达到平衡时, 氧化膜 的结构将不再变化, 表现为微孔分布均匀、孔径均一 的氧化铝多孔膜. 这个过程就是目前被普遍认可的 氧化铝多孔膜的自组织过程.

\section{References}

1 Gong, Y. L. ; Wang, W. ; Dong, X. H. ; Liu, X. L. ; Guo, H. T. J. Chem. Ind. \& Eng., 2001, 52(12): 1120 [巩运兰, 王 为, 董向红, 刘学雷, 郭鹤桐. 化工学报 (Huagong Xuebao), 2001, 52 (12): 1120]

2 Hideki, M. ; Masahiro, S. Jpn. J. Appl. Phys., 1996, 35(1B 15): 126

3 Shoso, S. ; Yasuhiko, M. ; Hiroyuki S. ; Takayuki, T. Jpn. J. Appl. Phys., 2002, 41: 340

$4 \quad$ Hideki, M. ; Kenji, F. Science, 1995, 268(9): 1466

5 Yucheng, S. ; Jose, M. S. Materials Letters, 2001, 48: 127

\title{
The Analysis of Self-organizing Process of Anodic Alumina Films with Nano-pore Array Structure*
}

\author{
Gong Yun-Lan ${ }^{1,2} \quad$ Wang Wei $^{1} \quad$ Wang Hui $^{1} \quad$ Guo He-Tong ${ }^{1}$ \\ ( ${ }^{1}$ Department of Applied Chemistry, School of Chemical Engineering, Tianjin University, Tianjin 300072 ; \\ ${ }^{2}$ School of Engineering, Tianjin University of Commerce, Tianjin 300134)
}

\begin{abstract}
With the increase of the anodizing time, the nanoporous morphology of the anodic porous alumina film formed by anodizing Al in an oxalic acid solution will change from irregular to regular and the distribution of nanoporous will also change from disarray to regular hexangular array. The results indicated that there was high internal stress in the barrier layer due to the severe mismatch between the barrier layer formed in early anodization and the Al substrate. The release of the internal stress resulted in the origination of the numerous nanoporous in the surface of the barrier layer, which accordingly made the surface energy of oxide film increase quickly. The internal stress in the walls and the surface tension in the surface of nanoporous acted together in the anodization and determined the morphology and distribution of the nanoporous in each phase of the anodization. When these two forces reached a balance, the nanoporous possessed excellent uniformity in diameter and spacing of the holes. At this time, the energy of the system is at the lowest. The transition process from unbalance to balance of the these two forces is the internal drive in the self-organized process of the porous configuration from the initial irregular through to regular array.
\end{abstract}

Keywords: Anodic alumina film, Nano-pore array structure, Self-organize, Inner stress, Surface tension 